\title{
Investigation of the Effect of Pre-Service Classroom Teachers' Critical Thinking Disposition on Their Media Literacy
}

\author{
Özkan Çelik, Halil Çokçalışkan, Alper Yorulmaz \\ Department of Elementary Education, Faculty of Education, Mugla Sitk1 Kocman University
}

\begin{tabular}{l}
\hline Article Info \\
\hline Article history: \\
Received Jun 22, 2018 \\
Revised Aug1, 2018 \\
Accepted Aug 12, 2018 \\
\hline
\end{tabular}

Keyword:

Critical thinking

Media literacy

Pre-service classroom teacher

\begin{abstract}
It is important to develop a critical perspective in terms of interpreting the messages to be given to the individuals through media and questioning the authenticity and content of these messages. It is therefore necessary to train the individuals called media literate who can critically perceive and evaluate the information conveyed through the media to increase the positive effects of the media and to reduce their negative effects as much as possible. The purpose of the study is to investigate the effect of the pre-service teachers' critical thinking disposition on their media literacy. The study employed the relational survey model, one of the quantitative research methods. In order to collect data, a personal information form, the Critical Thinking Disposition Scale, and the Media Literacy Level Determination Scale were used as the data collection instruments. As a result of the study, the critical thinking disposition of the pre-service teachers was found to be medium and their media literacy was found to be high. The critical thinking disposition was found to be varying significantly depending on their gender and grade level; their media literacy was found to be varying depending on grade level but not on gender. There is a positive but low relationship between critical thinking disposition and media literacy and critical thinking is a significant predictor of media literacy.
\end{abstract}

Copyright (C) 2018 Institute of Advanced Engineering and Science. All rights reserved.

\section{Corresponding Author:}

Third Author, Departement of Elementary Education, Mugla Sitkı Kocman University, Kotekli, Mugla County 48000, Turkey. Email: alperyorulmaz@mu.edu.tr

\section{INTRODUCTION}

The twenty-first century is an era in which technological developments and information production are continuing rapidly. Thus, education has started to attach greater importance to the development of various skills for individuals to catch up with the information age. One of these skills is critical thinking, which can be seen as the basic requirement for the development of some other skills such as entrepreneurship, reasoning and problem solving. Moreover, critical thinking is considered to be a basic skill to be possessed by all professionals [1]. This skill seems to be more important for the classroom teachers working in the first level of compulsory education as they are responsible for guiding the development of children who are at the most important stage of their development because a classroom teacher with developed critical thinking skill can make important contributions to the development of children's critical thinking skills.

When the concept of critical thinking is examined, it is possible to encounter different definitions and approaches. Drennan [2] defines it with the concepts of problem solving, decision making, making inferences and reasoning; Paul and Elder [3] defines it as the art of analysis and evaluation to foster thinking; Halpern [4] defines it as a means of increasing the desired behaviors through the use of cognitive skills or strategies; Ennis [5] defines it as a way of profound and reasonable thinking while making decisions; McPeck [6] defines it as the skill of skeptical analysis of the encountered new information. When all these definitions 
are examined, critical thinking can be expressed as the thinking and learning activity including higher order cognitive skills.

When the relevant literature is reviewed, it is seen that critical thinking has been researched in many different disciplines. In addition, when the research on critical thinking in the field of education is examined, it is seen that critical thinking has a positive effect on achievement, attitude and skills in different courses.

Another skill thought to be affected by critical thinking is media literacy. Media has become an important source of data vital to us as a result of technological developments. However, this does not mean that each data released by media is necessarily correct. Media can affect perceptions, attitudes and opinions by getting various ideas across masses [7,8]. For this reason, individuals should have critical point of views and media literacy so that they can analyze the data sent from a source to determine whether there is misinformation or distortion of data and can seek for confirmation; in short, they should be media literate.

Media literacy requires the effective use of media sources and analysis of the messages coming from media sources with a critical point of view. Thus, the media literacy of the individuals with developed critical thinking skill is also expected to be developed because the individuals thinking critically are in the pursuit of understanding the causes of events and of questioning the incidences they encounter [9]. The relationship between critical thinking and media literacy can be emphasized through the definition of media literacy. Media literacy can be defined as the ability of having access to the messages of media published in different sources, analyzing, evaluating and communicating them $[10,11,12,13]$. Thus, it can be argued that media literate individuals should have critical thinking skills in the consumption of media [14]. In other words, it is necessary to have critical thinking skills about media.

When the related literature is reviewed, it can be seen that there is a large amount of research on critical thinking and media literacy, the number of studies focusing on the relationship between critical thinking and media literacy is quite limited $[15,16,17,12,14]$. Thus, the aim of the present study is to identify the effect of the pre-service classroom teachers' critical thinking disposition on their media literacy. To reach this goal, this study seeks to find answers to the following questions:

$\checkmark$ What are the pre-service classroom teachers' critical thinking disposition and media literacy levels?

$\checkmark$ Do the pre-service classroom teachers' critical thinking disposition and media literacy vary significantly depending on gender and grade level?

$\checkmark \quad$ Is the pre-service classroom teachers' critical thinking disposition a significant predictor of their media literacy?

\section{RESEARCH METHOD}

This research study aiming to identify the impact of the pre-service classroom teachers' critical thinking disposition on their media literacy was conducted according to the relational survey model descriptive in nature. The relational survey model intends to identify the relationship between two or more variables and to elicit the degree of this relationship [18].

\subsection{Study Group}

The study group of the current research is comprised of a total of 303 pre-service classroom teachers from the Education Faculty of Muğla Sıktı Koçman University in 2017-2018 academic year. The distribution of the pre-service teachers according to their gender, grade level and grade point average is given in Table 1.

Table 1. Distribution of the pre-service teachers according to their gender, grade level and grade

\begin{tabular}{|c|c|c|c|c|c|c|c|c|c|c|c|}
\hline \multicolumn{12}{|c|}{ point average } \\
\hline \multirow{2}{*}{\multicolumn{2}{|c|}{ Grade }} & \multicolumn{2}{|c|}{$1^{\text {st }}$ year } & \multicolumn{2}{|c|}{$2^{\text {nd }}$ year } & \multicolumn{2}{|c|}{$3^{\text {rd }}$ year } & \multicolumn{2}{|c|}{$4^{\text {th }}$ year } & \multicolumn{2}{|c|}{ Total } \\
\hline & & $\mathrm{n}$ & $\%$ & $\mathrm{n}$ & $\%$ & $\mathrm{n}$ & $\%$ & $\mathrm{n}$ & $\%$ & $\mathrm{n}$ & $\%$ \\
\hline \multirow{2}{*}{ Gender } & Female & 49 & 22.9 & 52 & 24.3 & 68 & 31.8 & 45 & 21.0 & 214 & 70.6 \\
\hline & Male & 29 & 32.6 & 32 & 36.0 & 17 & 19.1 & 11 & 12.4 & 89 & 29.4 \\
\hline \multirow{6}{*}{$\begin{array}{c}\text { Grade Point } \\
\text { Average }\end{array}$} & 1.99 and lower & 7 & 31.8 & 10 & 45.5 & 3 & 13.6 & 2 & 9.1 & 22 & 7.3 \\
\hline & $2.00-2.49$ & 23 & 33.8 & 17 & 25.0 & 17 & 25.0 & 11 & 16.2 & 68 & 22.4 \\
\hline & $2.50-2.99$ & 24 & 21.8 & 32 & 29.1 & 33 & 30.0 & 21 & 19.1 & 110 & 36.3 \\
\hline & $3.00-3.49$ & 21 & 22.8 & 22 & 23.9 & 29 & 31.5 & 20 & 21.7 & 92 & 30.4 \\
\hline & 3.50 and higher & 3 & 27.3 & 3 & 27.3 & 3 & 27.3 & 2 & 18.2 & 11 & 3.6 \\
\hline & tal & 78 & 25.7 & 84 & 27.7 & 85 & 28.1 & 56 & 18.5 & 303 & 100 \\
\hline
\end{tabular}

As can be seen in Table 1,70\% of the pre-service teachers are females. This is natural as the department attended is more preferred by female students. In terms of the grade level variable, there is a 
balanced distribution across the levels. In terms of their grade point averages, a high majority of the preservice teachers have 2.50 or higher grade point averages.

\subsection{Data Collection Instruments}

In the present study, the Critical Thinking Disposition Scale developed by Akbıyık [19] and the Media Literacy Scale developed by Karataş [20] were used as data collection instruments. Furthermore, a personal information form to elicit personal information about gender, grade level and academic achievement was used.

Critical thinking disposition scale

The Critical Thinking Disposition Scale developed by Akbiyik [19] is a scale used to identify the critical thinking level of a person. The Critical Thinking Disposition Scale is a five-point Likert scale. It consists of a single dimension having 15 positive and 15 negative items, a total of 30 items. The internal consistency coefficient of the original scale is .87 ; in the current study it was found to be .89 .

Media literacy scale

The Media Literacy Scale developed by Karataş [20] is a scale proved to be reliable and valid to determine the media literacy of a person. The scale is a five-point Likert scale consisting of 17 items. It has three factors; having knowledge ( 7 items), being able to analyze (6 items) and being able to judge (4 items). The internal consistency coefficient of the original scale was found to be .72 for the dub-dimension of having knowledge, .72 for the sub-dimension of being able to analyze, .68 for the sub-dimension of being able to judge 0.68 and .84 for the whole scale. In this study, it was found to be .86 for the sub-dimension of having knowledge, .82 for the sub-dimension of being able to analyze, .77 for the sub-dimension of being able to judge and .92 for the whole scale.

\subsection{Data Collection}

The data were gathered by the researchers going to the classes in the Department of Classroom Teacher Education in July 2018 after having taken the required permissions. The participation was on a volunteer basis. After the collection of the scales, the uncompleted or erroneously completed scales were discarded and a total of 303 scales were entered into the data base.

\subsection{Data Analysis}

There are two different scales that were used in the present study. First, the reliability coefficients for the scales were calculated. Then, the mean and standard deviation values for the scales and their subdimensions were found. Büyüköztürk [21] states that when the number of sub-groups is 15 or more, the use of parametric statistics does not lead to significant deviation in the significance level. Yet, in order to determine whether the scores taken from the scales exhibit a normal distribution or not, Kurtosis and skewness coefficients were calculated. Kurtosis and skewness values in the range of +1 and -1 show that the distribution is normal. The skewness coefficient for the scores of the critical thinking disposition scores was found to be .177 and the Kurtosis coefficient was found to be -.775 ; the skewness coefficient for the media literacy scores was found to be -.491 and the Kurtosis coefficient was found to be .939 . These values show that the distribution is normal.

In order to identify the pre-service classroom teachers' critical thinking disposition and media literacy, descriptive analyses were used. In this regard, the states of the participants are defined as follows depending on their scores taken from the scales: 1-2.33 "low", 2.34-3.67 "medium", 3.68-5.00 "high". In order to determine whether the participants' level of media literacy varies significantly depending on gender, $\mathrm{t}$-test; one of the parametric analyses, was used and to determine whether it varies significantly depending on grade level, variance analysis was used. In order to determine the source of difference, Dunnett C, one of the Post-Hoc analysis techniques, was used. Moreover, regression analysis was run to determine the effect of critical thinking disposition on media literacy. The findings of the analyses are presented below.

\section{FINDINGS}

The results of the analyses obtained for the sub-problems of the study determined are presented in tables and then interpreted.

The findings related to the pre-service classroom teachers' critical thinking disposition and media literacy levels are presented in Table 2 and Table 3.

As can be seen in Table 2, the pre-service teachers' critical thinking disposition and media literacy

means are $\overline{\mathrm{x}}=3.60$ " and " $\overline{\mathrm{x}}=3.79$, respectively. The pre-service classroom teachers' critical thinking disposition was found to be "medium", media literacy level was found to be "high". Moreover, when the pre-

IJERE Vol. 7, No. 3, September 2018: $194-202$ 
service classroom teachers' media literacy was examined in terms of its sub-dimensions, it was found that "having knowledge" and "being able to judge" are high and "being able to analyze" is medium.

As it can be seen in Table 3, the critical thinking disposition of 154 pre-service teachers is medium and the critical thinking disposition of 149 pre-service teachers is high. The media literacy level of 196 preservice teachers is high, that of 102 pre-service teachers is medium and that of 5 pre-service teachers is low.

Table 2. Descriptive statistics concerning the pre-service classroom teachers' critical thinking disposition and

\begin{tabular}{ccccc}
\multicolumn{5}{c}{ media literacy levels } \\
$\mathrm{N}$ & $\overline{\mathrm{X}}$ & ss & Level \\
\hline Critical thinking disposition & 303 & 3.60 & .48 & Medium \\
Media literacy & 303 & 3.79 & .57 & High \\
Having knowledge & 303 & 3.94 & .59 & High \\
Being able to analyze & 303 & 3.67 & .67 & Medium \\
Being able to judge & 303 & 3.72 & .66 & High \\
\hline
\end{tabular}

Table 3. Distribution of the pre-service classroom teachers according to their critical thinking disposition and media literacy levels

\begin{tabular}{ccccccccc}
\hline & \multicolumn{2}{c}{ Low } & \multicolumn{2}{c}{ Medium } & \multicolumn{2}{c}{ High } & \multicolumn{2}{c}{ Total } \\
& $\mathrm{n}$ & $\%$ & $\mathrm{n}$ & $\%$ & $\mathrm{n}$ & $\%$ & $\mathrm{n}$ & $\%$ \\
\hline Critical thinking disposition & - & 0 & 154 & 50.8 & 149 & 49.2 & 303 & 100 \\
Media literacy & 5 & 1.7 & 102 & 33.7 & 196 & 64.7 & 303 & 100 \\
\hline
\end{tabular}

The findings showing whether the pre-service teachers' critical thinking disposition and media literacy level vary significantly depending on gender are presented in Table 4.

Table 4. T-test results concerning the pre-service classroom teachers' critical thinking disposition and media literacy scores in relation to the gender variable

\begin{tabular}{ccccccccc}
\hline & Groups & $\mathrm{N}$ & $\overline{\mathrm{X}}$ & $\mathrm{S}$ & $\mathrm{Sd}$ & $\mathrm{t}$ & $\mathrm{p}$ & $\mathrm{d}$ \\
\hline \multirow{2}{*}{ Critical thinking disposition } & Females & 214 & 3.64 & .46 & 301 & 2.25 & .02 & .41 \\
& Males & 89 & 3.50 & .51 & & & \\
\multirow{2}{*}{ Media literacy level } & Females & 214 & 3.78 & .54 & 301 & -.85 & .39 & - \\
& Males & 89 & 3.84 & .65 & & \\
& & &
\end{tabular}

The t-test results presented in Table 4 related to the pre-service classroom teachers' critical thinking disposition scores in relation to the gender variable are examined, it is seen that the critical thinking disposition mean scores of the female and male pre-service teachers are $\bar{x}=3,64$ and $\bar{x}=3,50$, respectively. The t-test results have revealed that the critical thinking mean scores of the female and male students vary significantly by gender in favor of the female students $\left[\mathrm{t}_{(301)}=2,25 ; \mathrm{p}<.05\right]$. On the other hand, it has been revealed that the difference between the media literacy mean scores of the female and male students is not statistically significant $\left[\mathrm{t}_{(301)}=-, 85 ; \mathrm{p}>.05\right]$. Thus, it can be argued that while the pre-service teachers' critical thinking disposition varies significantly depending on gender, their media literacy levels do not vary significantly depending on gender.

The findings showing whether the pre-service classroom teachers' critical thinking disposition varies significantly depending on the grade level variable are presented in Table 5.

Table 5. Results of One Way ANOVA conducted to determine whether the pre-service teachers' critical thinking disposition varies significantly depending on grade level

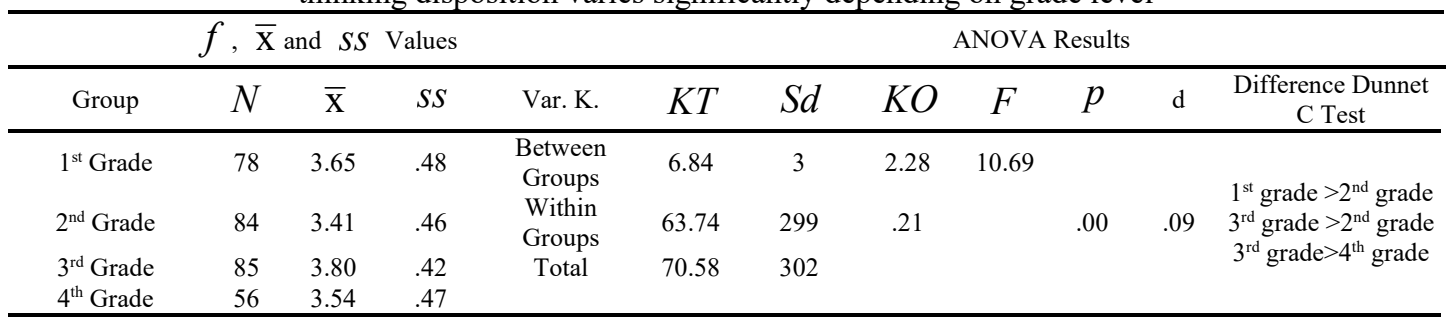

As can be seen in Table 5, the pre-service classroom teachers' scores for their critical thinking disposition vary significantly depending on grade level $\left[\mathrm{F}_{(299)}=10.69, \mathrm{p}<.00, \mathrm{~d}=.09\right]$. In order to determine 
the source of the difference, Dunnet $\mathrm{C}$ test was run. The difference was found to be between $1^{\text {st }}$ and $2^{\text {nd }}$ grade levels in favor of $1^{\text {st }}$ grade level, between $3^{\text {rd }}$ grade and $2^{\text {nd }}$ grade levels in favor of $3^{\text {rd }}$ and between $3^{\text {rd }}$ and $4^{\text {th }}$ grade levels in favor of $3^{\text {rd }}$ grade level.

The results of the analysis conducted to reveal whether the pre-service classroom teachers' media literacy level varies significantly depending on grade level are given in Table 6 .

Table 6. Results of One Way ANOVA conducted to determine whether the pre-service teachers' media literacy varies significantly depending on grade level

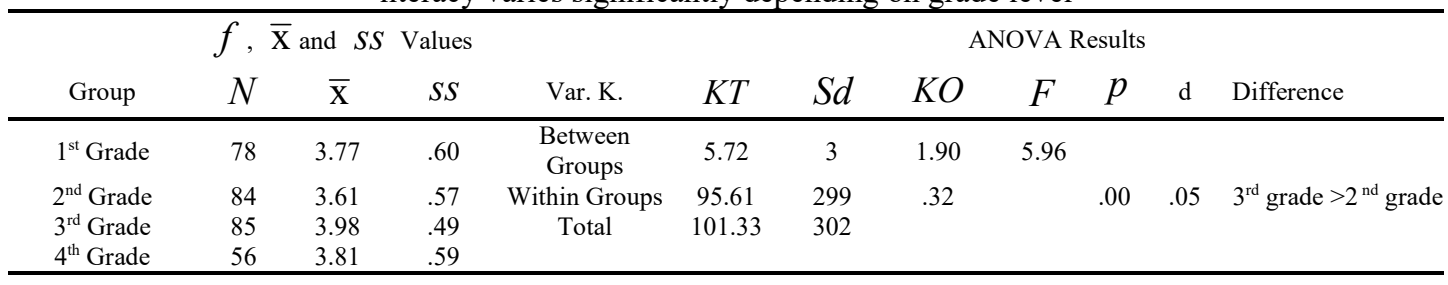

As can be seen in Table 6, the pre-service classroom teachers' scores for their media literacy vary significantly depending on grade level $\left[\mathrm{F}_{(299)}=5.96, \mathrm{p}<.00, \mathrm{~d}=.05\right]$. In order to determine the source of this difference, Dunnet $\mathrm{C}$ test was conducted. This difference was found to be between $3^{\text {rd }}$ and $2^{\text {nd }}$ grade levels in favor of $3^{\text {rd }}$ grade level.

Pearson Correlation Coefficient analysis conducted to reveal the correlation between the pre-service classroom teachers' critical thinking disposition scores and media literacy scores are given in Table 7.

Table 7. Pearson Correlation Coefficient Test results related to the relationship between the pre-service classroom teachers' critical thinking disposition and media literacy level

\begin{tabular}{lccccc}
\hline Variables & $\begin{array}{c}\text { Critical } \\
\text { thinking } \\
\text { disposition }\end{array}$ & $\begin{array}{c}\text { Media } \\
\text { literacy }\end{array}$ & $\begin{array}{c}\text { Having } \\
\text { knowledge }\end{array}$ & $\begin{array}{c}\text { Being able to } \\
\text { analyze }\end{array}$ & Being able to judge \\
\hline Critical thinking disposition & - & $.38^{* *}$ & $.43^{* *}$ & $.27^{* *}$ & $.34^{* *}$ \\
\hline Media literacy & & - & $.92^{* *}$ & $.90^{* *}$ & $.87^{* *}$ \\
\hline Having knowledge & & - & $.71^{* *}$ & $.74^{* *}$ \\
\hline Being able to analyze & & & - & $.70^{* *}$ \\
\hline Being able to judge & & & & - \\
\hline $303, * * \mathrm{p}<.01$ & & & \\
\hline
\end{tabular}

Correlation analysis is used to determine and interpret the relationships between two variables. If the correlation coefficient value is $0.70-1.00$, it is considered to be "high", if it is $0.70-0.30$, then it is considered to be "medium" and if it is $0.30-0.00$ then it is considered to be "low" [21]. As can be seen in Table 7, there is a positive and significant correlation between their critical thinking disposition and media literacy and subdimensions of media literacy $(\mathrm{p}<.01)$. The correlation between critical thinking disposition and media literacy was found to be positive and medium $(\mathrm{r}=.38)$. The correlation between critical thinking disposition and the media literacy's sub-dimensions of "having knowledge $(\mathrm{r}=.43)$ " and "being able to judge ( $\mathrm{r}=.34)$ " is positive and medium. There is a significant and low correlation with the other sub-dimension of media literacy "being able to analyze" $(\mathrm{r}=27)$ ".

The results of the regression analysis conducted to determine the extent to which the pre-service classroom teachers' critical thinking disposition predicts their media literacy are given in Table 8 .

Table 8. The extent to which the pre-service classroom teachers' critical thinking disposition predicts their

\begin{tabular}{ccccccccc}
\hline \multicolumn{10}{c}{ media literacy } \\
\hline & $\mathrm{R}$ & $\mathrm{R}^{2}$ & $\mathrm{~F}$ & $\mathrm{~B}$ & $\mathrm{Sd}$ & $\mathrm{Beta}$ & $\mathrm{t}$ & $\mathrm{p}$ \\
\hline Critical thinking disposition & .38 & .15 & 53.37 & .46 & .06 & .38 & 7.30 & $.00^{*}$ \\
\hline
\end{tabular}

As can be seen in Table 8, as a result of the simple linear regression analysis conducted to determine the extent to which the pre-service classroom teachers' critical thinking disposition predicts their media

IJERE Vol. 7, No. 3, September 2018: $194-202$ 
literacy, a correlation was found between critical thinking disposition and media literacy $\left(\mathrm{R}=.38, \mathrm{R}^{2}=.15\right)$. Critical thinking disposition was found to be a significant predictor of media literacy $\left(\mathrm{F}_{(1-302)}=53.37, \mathrm{p}<.05\right)$. Critical thinking disposition explains $15 \%$ of the scores obtained for media literacy. The significance test of the principal predictor variable coefficient $(B=.46)$ in the regression equation also revealed that critical thinking disposition is a significant predictor $(\mathrm{p}<.01)$.

\section{DISCUSSION, RESULTS AND SUGGESTIONS}

As a result of the current study, the pre-service classroom teachers' critical thinking disposition was found to be medium. Though medium level of critical thinking disposition seems to be good, it might be not enough for the classroom teachers of future. When the relevant literature is examined, it is seen that though most of the studies have reported that pre-service classroom teachers' critical thinking levels are not adequate $[22,23,24,25,9,26,27]$, there are some other studies reporting that pre-service classroom teachers' critical thinking levels are good or high $[28,29,30,31,32,33,34,35,36,37,38,39,40]$ and some others reported that their critical thinking levels are very low [41, 24, 42, 43, 44, 45].

The current study also found that the pre-service classroom teachers' media literacy levels are high. Moreover, when the sub-dimensions of media literacy were examined, it was found that the pre-service teachers have high levels of "having knowledge" and "being able to judge" and medium level of "being able to analyze". These findings seem to be promising for the pre-service teachers to be able to make use of media elements in their daily lives and educational and instructional activities because as the teachers of future, they will be able to impart this skill to their prospective students.

The pre-service classroom teachers' critical thinking disposition was found to be varying significantly by gender in favor of the female pre-service teachers. Saracaloğlu and Yılmaz [46] also investigated the relationship between the pre-service classroom teachers' critical thinking disposition and the gender variable and found a significant difference in favor the female pre-service teachers. Thus, their finding concurs with the finding of the current study. Moreover, they found the effect size of the gender variable to be medium. Ay and Akgöl [47], in their study entitled "Critical Thinking Power and Gender, Age and Grade Level", found that the students' critical thinking power varies significantly by gender in favor of the female students. Female students' having higher cores is a finding parallel to the findings reported by many other studies $[27,44,48,49,50,51,52,53,53,54,55,56]$.

The pre-service classroom teachers' media literacy was found to be not varying significantly depending on gender.

When the pre-service classroom teachers' critical thinking disposition was examined in relation to the grade level variable, significant differences were found between $1^{\text {st }}$ grade and $2^{\text {nd }}$ grade students, between $3^{\text {rd }}$ grade and $2^{\text {nd }}$ grade students and between $3^{\text {rd }}$ grade and $4^{\text {th }}$ grade students. Moreover, the effect size of the grade level variable was found to be low. Although in many studies [47, 41, 58, 53, 59, 60, 61, 62] it was found that with increasing grade level, the level of critical thinking is also increasing, in the current study and in some other studies [52, 32], the exact opposite was found to be true; with increasing grade level, the level of critical thinking is decreasing. In another study, the pre-service teachers' critical thinking scores were found to be not varying depending on grade level. This seems to comply with the findings of the study conducted by Ekinci and Aybek [63] to investigate the emphatic and critical thinking disposition of 671 preservice teachers.

When the correlation between the pre-service classroom teachers' media literacy and grade level was examined, it was found that there is a significant difference between the $3^{\text {rd }}$ grade and $2^{\text {nd }}$ grade students in favor of the $3^{\text {rd }}$ grade students. Moreover, effect size of the grade level variable was found to be low.

A positive, significant and low correlation was found between the pre-service classroom teachers' critical thinking disposition and media literacy level and the sub-dimensions of media literacy. Moreover, critical thinking disposition was found to be a significant predictor of media literacy. Critical thinking disposition was found to be explaining $15 \%$ of the total variance in media literacy. This seems to comply with the results of the study carried out by Semerci and Semerci [64] to determine the effect of the critical literacy of teacher candidates on their media literacy. In this respect, it can be argued that in order to be able to foster media literacy of students, first their critical thinking disposition should be improved. Critically thinking individuals evaluate an event or issue not from a single perspective but from multiple perspectives. Therefore, critically thinking individuals can look at the issues appearing in different sources of media from different perspectives; thus, they see alternatives not a single truth.

Considering the results of the present study, following suggestions can be made.

$\checkmark \quad$ The current study revealed that there is a correlation between critical thinking and media literacy. Yet, while the pre-service teachers' critical thinking disposition was found to be high in general, their media literacy level was found to be medium. Thus, the pre-service teachers can be given 
courses with the content of media literacy and can be instructed about how to make use of critical thinking in developing their media literacy.

$\checkmark$ Conducting experimental and qualitative research with different data collection tools on critical thinking and media literacy is believed to make contributions to the literature.

\section{REFERENCES}

[1] S. Arslantaş and A. Kurnaz, A, "Konu başlığında 'eleștirel düşünme' kavramı geçen, YÖK veri tabanına kayıtlı yüksek lisans ve doktora tezlerinin farklı değişkenlere göre sınıflandırılması” ISCAT2015 Sakarya -Turkey, 2015.

[2] J. Drennan, "Critical thinking as an outcome of master's degree in nursing programme", Journal of Advanced Nursing, 66(2), 422-431, 2010.

[3] R. Paul and L. Elder, "The miniature guide to critical thinking concepts and tools," Dillon Beach: Foundation for Critical Thinking Press, 2008.

[4] D.F. Halpern, "Thought knowledge: An introduction to critical thinking," London: Lawrence Erlbaum Associates. (5th Press), 2013.

[5] R.H. Ennis, "Goals for critical thinking curriculum." A. Costa (ed), Developing minds: A source book for teaching thinking. Virginia: Association For Supervision And Curriculum Development, pp. 54-57, 1989.

[6] J.E. McPeck, “Critical thinking and education,” England Oxford: Martin Robenson, 1981.

[7] J.R. Eshleman and R. Bullcroft, "The family," 12th edition, NJ: Prentice Hall, 2009.

[8] M.N. Gömleksiz and B. Duman, "Medya okuryazarlığı dersi kazanımlarının gerçekleşme düzeyine ilişkin öğrenci ve okul yöneticilerinin görüşleri," Turkish Studies -International Periodical for the Languages, Literature and History of Turkish or Turkic, 8(9), pp. 265-278, 2013.

[9] S.M. Özdemir, "Üniversite öğrencilerinin eleştirel düşünme becerilerinin çeşitli değişkenler açısından değerlendirilmesi," Türk Ĕ̈itim Bilimleri Dergisi, 3(3), pp. 1-17, 2005.

[10] B. Arslan-Cansever, "Turkish teacher candidates' perceptions of the "media literate individual" through metaphors," International Journal of Scientific Research in Education, 6(2), pp.204-213, 2013.

[11] H. Arslan, "Eleştirel medya okuryazarlığı kapsamında çocuk odaklı haber ve programlar üzerine bir değerlendirme,” Adnan Menderes Üniversitesi Sosyal Bilimler Enstitüsü Dergisi, 1(2), pp. 71-79, 2014.

[12] A.A. Kurt and D. Kürüm, "Medya okuryazarlığı ve eleştirel düşünme arasındaki ilişki: Kavramsal bir bakış," Mehmet Akif Ersoy Üniversitesi Sosyal Bilimler Enstitüsü Dergisi, 2(2), pp. 20-34, 2010.

[13] E. Thoman and T. Jolls, "Literacy for the 21st century an overview \& orientation guide to media literacy education," Center for Media Literacy, 2003

[14] A. Nalçacı, E. Maral and İ.F. Şahin, "Sosyal bilgiler öğretmen adaylarının eleştirel düşünme ile medya okuryazarlıkları arasındaki ilişki," Doğu Coğrafya Dergisi, 21(36), pp.1-12, 2017.

[15] B. Aybek and R. Demir, "Lise öğrencilerinin medya ve televizyon okur yazarlık düzeyleri ile eleştirel düşünme eğilimlerinin incelenmesi," Çukurova Üniversitesi Sosyal Bilimler Enstitüsü Dergisi, 22 (2), ss.287-304, 2013.

[16] M. Feuerstein, "Media literacy in support of critical thinking," Journal of Educational Media, 24 (1), pp.43-54, 1999.

[17] M.K. Karaman, "Öğretmen adaylarının medya okuryazarlık düzeyleri ve eleştirel düşünme eğilimleri üzerine bir araştırma," Gümüşhane Üniversitesi İletişim Fakültesi Elektronik Dergisi, 4(1), pp. 326-350, 2016.

[18] N. Karasar, "Bilimsel araştırma yöntemi”, Ankara: Nobel Yayın Dağıtım, 2010.

[19] C. Akbıyık, "Eleştirel düşünme eğilimleri ve akademik başarı," Yayımlanmamış Yüksek Lisans Tezi, Hacettepe Üniversitesi Sosyal Bilimler Enstitüsü, Ankara, 2002.

[20] A. Karataş, "Öğretmen adaylarının medya okuryazarlık düzeyleri”, Yayımlanmamış Yüksek Lisans Tezi, Afyon Kocatepe Üniversitesi Sosyal Bilimler Enstitüsü, Afyon, 2008.

[21] Ş. Büyüköztürk, "Veri analizi el kitabl”, Ankara: Pegem Yayıncılık, 2010.

[22] F. Aliustaoğlu and A. Tuna, A, "Öğretmen adaylarının eleştirel düşünme eğilimlerinin incelenmesi (Kastamonu Üniversitesi Örneği),” INES Journal, 2(4), pp. 131-142, 2015.

[23] T. Argon and Ç. Selvi, "Öğretmen adaylarının eleştirel düşünme eğilimleri ve çatışma yönetim stilleri," WJEIS, 1(1), pp. 93-100, 2011

[24] Ü. Akar, "Öğretmen adaylarının bilimsel süreç becerileri ve eleştirel düşünme beceri düzeyleri arasındaki ilişki," Yayımlanmamış Yüksek Lisans Tezi, Afyon Kocatepe Üniversitesi Sosyal Bilimler Enstitüsü, 2007

[25] M. Güven and D. Kürüm, D, "Öğretmen adaylarının öğrenme stilleri ile eleştirel düşünme eğilimleri arasındaki ilişki," İlköğretim Online, 7(1), pp. 53-70, 2008.

[26] D. Tufan, "Öğretmen adaylarının eleştirel düşünme becerileri: Orta Doğu Teknik Üniversitesi yabancı dil öğretmenliği örneği”, Yayımlanmamış yüksek lisans tezi, Orta Doğu Teknik Üniversitesi Sosyal Bilimler Enstitüsü, Ankara, 2008.

[27] K. Zayif, "Öğretmen adaylarının eleştirel düşünme eğilimleri,” Yayımlanmamış yüksek lisans tezi. Abant İzzet Baysal Üniversitesi Sosyal Bilimler Enstitüsü, Bolu, 2008.

[28] E.G. Cengiz, "Üniversite öğrencilerine yönelik eleştirel düşünme etkinliklerinin eleştirel düşünme eğilimi ve becerileri açısından değerlendirilmesi,” Yayınlanmamış yüksek lisans tezi, Ankara Üniversitesi Eğitim Bilimleri Enstitüsü, Ankara, 2004.

[29] A. Çetin, "Sınıf öğretmeni adaylarının eleştirel düşünme gücü,” Yayımlanmamış yüksek lisans tezi, Uludağ Üniversitesi Sosyal Bilimler Enstitüsü, Bursa, 2008.

IJERE Vol. 7, No. 3, September 2018: $194-202$ 
[30] H. Hamurcu, G. Akamca and Y. Günay, "Fen bilgisi ve sınıf öğretmenliği anabilim dalı öğrencilerinin eleştirel düşünmeye yönelik görüşleri," Ondokuz Mayıs Üniversitesi Eğitim Fakültesi Dergisi, 20, pp.12-25, 2005.

[31] Ç. Aldan-Karademir, "Öğretmen adaylarının sorgulama ve eleştirel düşünme becerilerinin öğretmen öz yeterlik düzeyine etkisi," Yayımlanmamış doktora tezi, Adnan Menderes Üniversitesi Sosyal Bilimler Enstitüsü, Aydin, 2013.

[32] B. Koçak, Y. Kurtlu, H. Ulaş and C. Epçaçan, "Sınıf öğretmeni adaylarının eleştirel düşünme düzeyleri ve okumaya yönelik tutumları arasındaki ilişki," Ekev Akademi Dergisi, 19(61), pp. 211-228, 2015.

[33] S.L. Kong, "Critical thinking dispositions of pre-service teachers in Singapore: A preliminary investigation. AARE Annual Conference, Fremantle, 2001.

[34] Ü. Şen, "An evaluation about Turkish teacher candidates'critical thinking attitude's in terms of difference variable," Journal of World of Turks, 1(2), pp. 69-89, 2009.

[35] D. Şahhüseyinoğlu, "Eleştirel düşünme ve eğitsel oyunlar: İngiliz dili aday öğretmenlerinin görüşleri," Hacettepe Üniversitesi Ĕ̈itim Fakültesi Dergisi, 32, pp. 266-273, 2007.

[36] E. Tok, "Düşünme becerileri eğitim programının okul öncesi öğretmen adaylarının eleştirel, yaratıcı düşünme ve problem çözme becerilerine etkisinin incelenmesi," Yayımlanmamış doktora tezi, Marmara Üniversitesi Eğitim Bilimleri Enstitüsü, İstanbul, 2008.

[37] I.J. Quitadamo, "Critical thinking higger education: The influence of teaching styles and peer collaboration on science and math learning," Unpublished doctor of philosaphy thesis, Washington State University, 2002.

[38] H.İ. Yıldırım, "Eleştirel düşünmeye dayalı fen eğitiminin öğrenme ürünlerine etkisi," Yayınlanmamış doktora tezi, Gazi Üniversitesi Eğitim Bilimleri Enstitüsü, Ankara, 2009.

[39] Ö.S. Yılmaz, "Eleştirel düşünme tutumunu etkileyen faktörler: Sınıf öğretmeni adayları üzerine bir çalışma," Yayımlanmamış doktora tezi, Adnan Menderes Üniversitesi Sosyal Bilimler Enstitüsü, Aydın, 2012.

[40] C. Yoldaş, "Çevre bilimi dersinin sınıf öğretmeni adaylarının eleştirel düşünme becerileri, erişileri ve tutumlarına etkisi," Yayınlanmamış doktora tezi, Dokuz Eylül Üniversitesi Eğitim Bilimleri Enstitüsü, İzmir, 2009.

[41] S. Açışl1, S, (2016). "Sınıf öğretmeni adaylarının öğrenme stilleri ile eleştirel düşünme eğilimlerinin incelenmesi," Illkögretim Online, 15(1), pp. 273-285, 2016.

[42] S. Alkın-Şahin, N. Tunca and Ö. Ulubey, "Öğretmen adaylarının eğitim inançları ile eleştirel düşünme eğilimleri arasındaki ilişki,” Illköğretim Online, 13(4), pp. 1473-1492, 2014.

[43] H. Gülveren, "Eğitim fakültesi öğrencilerinin eleştirel düşünme becerileri ve bu becerileri etkileyen eleştirel düşünme faktörleri," Yayınlanmamış doktora tezi, Dokuz Eylül Üniversitesi Eğitim Bilimleri Enstitüsü, İzmir, 2007.

[44] D. Kürüm, "Öğretmen adaylarının eleştirel düşünme gücü," Yayınlanmamış yüksek lisans tezi, Anadolu Üniversitesi Eğitim Bilimleri Enstitüsü, Eskişehir, 2002.

[45] E. Şenşekerci and H. Kartal, "Öğretmen adaylarının eleştirel düşünme eğilimleri," E-Journal of New World Sciences Academy, 5(3), pp. 839-857, 2010.

[46] S. Saracaloğlu and S. Yılmaz, "Öğretmen adaylarının eleştirel düşünme tutumları ile denetim odaklarının incelenmesi," Illköğretim Online, 10(2), pp. 468-478, 2011.

[47] Ş. Ay and H. Akgöl, "Eleştirel düşünme gücü ile cinsiyet, yaş ve sınıf düzeyi," Kuramsal Eğitim Bilim, 1(2), pp. $65-75,2008$.

[48] R. Arslan, H. Gülveren and E.A. Aydın, "Research on critical thinking tendencies and factors that affect critical thinking of higher education students," International Jo-urnal of Business and Management, 9 (5), pp. 43-59, 2014.

[49] B. Aybek, "Konu ve beceri temelli eleştirel düşünme öğretiminin öğretmen adaylarının eleştirel düşünme eğilimi ve düzeyine etkisi," Yayımlanmamış doktora tezi, Çukurova Üniversitesi Sosyal Bilimler Enstitüsü, Adana, 2006.

[50] S. Çekiç, "Matematik öğretmenliği lisans öğrencilerinin eleştirel düşünme gücü düzeylerinin bazı değişkenlere göre incelenmesi," Yayınlanmamış yüksek lisans tezi, Dokuz Eylül Üniversitesi Sosyal Bilimler Enstitüsü, İzmir, 2007.

[51] Z. Çetinkaya, "Türkçe öğretmen adaylarının eleştirel düşünmeye ilişkin görüşlerinin belirlenmesi," Ahi Evran Üniversitesi Ĕ̌itim Fakültesi Dergisi, 12(3), pp. 93-108, 2011.

[52] P.A. Facione, C. Giancarlo, N. Facione and J. Gainen, "The disposition toward critical thinking," Journal of General Education, 44 (1), pp. 1-25, 1995.

[53] D.L. Gilstrap and J.A. Dupree, "Regression model of predictor variables on critical reflection in the classroom: Integration of the critical incident questionnaire and the framework for reflective thinking," The Journal of Academic Librarianship, 34(6), pp. 469-481, 2008.

[54] D. Kökdemir, "Belirsizlik durumlarında karar verme ve problem çözme," Yayımlanmamış doktora tezi, Ankara Üniversitesi Sosyal Bilimler Enstitüsü, Ankara, 2003.

[55] G. Ocak, E. Eymir and İ. Ocak, "Öğretmen adaylarının eleştirel düşünme eğilimlerinin çeşitli değişkenler açısından incelenmesi," Erzincan Üniversitesi Eğitim Fakültesi Dergisi, 18(1), pp. 63-91, 2016.

[56] Z. Özsoy-Güneş, Ç. Çıngıl-Barış and F.G. Kırbaşlar, "Fen bilgisi öğretmen adaylarının matematik okuryazarlığı özyeterlik düzeyleri ile eleştirel düşünme eğilimleri arasındaki ilişkilerin incelenmesi," Hasan Ali Yücel Ĕ̈itim Fakültesi Dergisi, 19(1), pp. 47-64, 2013.

[57] R. Rudd, M. Baker and T. Hoover, "Undergraduate agriculture learning style and critical thinking abilities: Is there a relationship?" Journal of Agricultural Education, 41 (3), pp. 2-12, 2000.

[58] S. Dil, "Hacettepe Üniversitesi Hemşirelik Yüksekokulu öğrencilerinin eleştirel düşünme düzeyleri," Yayınlanmamış yüksek lisans tezi, Hacettepe Üniversitesi Sağlık Bilimleri Enstitüsü, Ankara, 2001.

[59] T. Kartal, "İlköğretim Fen Bilgisi öğretmen adaylarının eleştirel düşünme eğilimlerinin incelenmesi," Ahi Evran Üniversitesi Kırşehir Eğitim Fakültesi Dergisi, 13 (2), pp. 279-297, 2012. 
[60] N. Öztürk, "Hemşirelik öğrencilerinin eleştirel düşünme düzeyleri ve eleştirel düşünmeyi etkileyen faktörler," Yayınlanmamış yüksek lisans tezi, Cumhuriyet Üniversitesi Sağlık Bilimleri Enstitüsü, Sivas, 2006.

[61] J. Profetto-McGrath, "The relationship of critical thinking skills and critical thinking dispositions of baccalaureate nursing students," Journal of Advanced Nursing, 43(6), pp. 569-577, 2003.

[62] J. Scott, R.J. Markert and M.M. Dunn, M.M, "Critical thinking: Change during medical school and relationship to performance in clinical clerk ships," Medical Education, 32, pp.14-18, 1998.

[63] Ö. Ekinci and B. Aybek, "Öğretmen adaylarının empatik ve eleştirel düşünme eğilimlerinin incelenmesi," Illkögretim Online, 9(2), pp. 816-827, 2010.

[64] N. Semerci and Ç. Semerci, "The effect of teacher candidates' critical literacy levels on their media literacy levels," Universal Journal of Educational Research, 5(12A), pp. 13-18, 2017.

\section{BIBLIOGRAPHY OF AUTHORS}
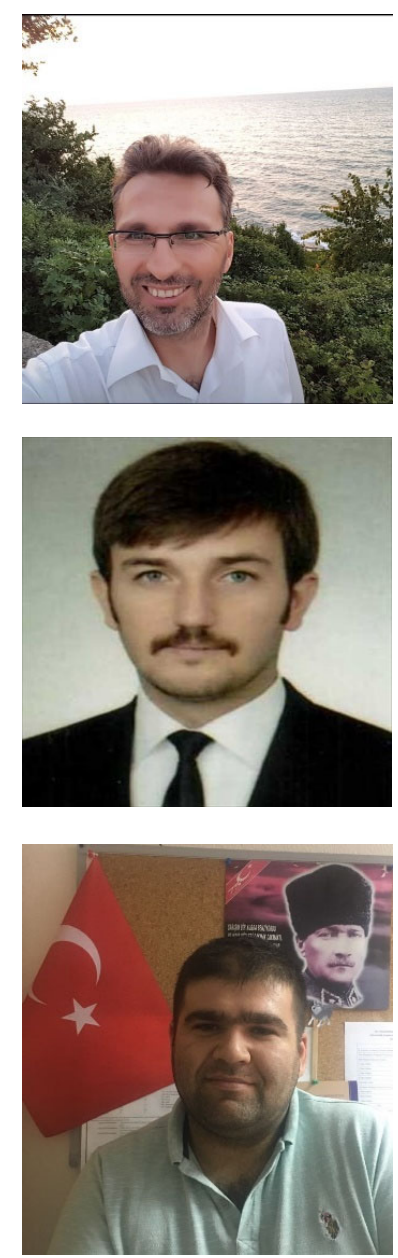

Özkan Çelik was born in Burdur in 1981. He completed his education life in various schools of Denizli. In 1998, he started to Ege University Computer Programming Department and graduated in 2000 as department third. In 2005, he graduated from Muğla University, Faculty of Education Department of Primary Teaching. This year he started to work as a teacher of Bingöl. At the end of the same year hestarted to work as a research assistant at Muğla Sitkı Koçman University. He completed his master's degree in Education Programs and Teaching in 2010. He completed his Ph.D. in 2015 and still he works in Mugla Sitk1 Kocman University. The author has a large number of studies on value education, creative drama, teacher education and teaching social studies.

Halil Çokçalişkan, researcher, has been studying for doctorate at Marmara University, Primary Education Program. He has been working as a research assistant at Muğla Sitk1 Koçman University, Faculty of Education, Department of Primary Education, Primary Education Program. His research interests are science education for primary level students, primary teacher training, learning and teaching skills.

Researcher Alper Yorulmaz has completed his Ph.D. in Marmara University Classroom Teaching. He has been working at Muğla Sitkı Koçman University, Faculty of Education, Elementary Education Department, Primary Education Program. His research interests are Mathematics Education for primary level students, primary teacher training, learning and teaching skills. 